\title{
DEMOGRAFI POLITIK SUMATERA UTARA: ANALISIS PILIHAN POLITIK MASYARAKAT BERDASARKAN PERSEBARAN PENDUDUK, AGAMA DAN ETNIS DALAM PEMILIHAN GUBERNUR SUMATERA UTARA TAHUN 2018 DI KOTA MEDAN
}

\author{
Budi Ali Mukmin', Muhammad Ridha Syafii Damanik² \\ 1Jurusan Pendidikan Pancasila dan Kewarganegaraan Fakultas Ilmu Sosial Universitas Negeri Medan \\ 2Jurusan Pendidikan Geografi Fakultas Ilmu Sosial Universitas Negeri Medan \\ Jl. Willem Iskandar Psr V Medan Estate Medan, 20211 Indonesia \\ Email: bamsarumpaet@gmail.com
}

\begin{abstract}
Abstrak
Studi demografi memberikan kemudahan bagi kajian ilmu politik dalam hal pemetaan potensi diluar dari variabel non-demografi. Jika studi demografi memberikan data kuantitatif yang berkaitan tentang jumlah populasi penduduk, golongan usia, data gender, tingkat pendidikan dan tingkat pendapatan ekonomi, maka kajian ilmu politik dapat menjadikan data tersebut untuk penentuan basis para pemilih yang dilihat dari jumlah penduduk, mampu mengetahui isu apa yang tepat untuk kampanye yang dilihat dari usia penduduk, kajian ilmu politik mampu mengemas isu kampanye yang tepat jika dapat dilihat dari tingkat pendidikan dan pendapatan ekonomi. Demografi politik di Sumatera Utara pada pilkada Sumatera Utara tahun 2018 menyuguhkan data yang menarik untuk dianalisis. Kota Medan yang dijadikan sebagai lokus kajian memberikan sinyalemen bahwa pola persebaran penduduk yang berdomisili pada masing-masing Kecamatan di Kota Medan tidak bisa dianggap sebagai pola domisili biasa. Jika ditelisik lebih jauh pola pemukiman penduduk di Kota Medan ternyata telah membentuk pola pemukiman yang dihuni berdasarkan kesamaan agama, kesamaan etnis, dan kesamaan asal daerah pada masing-masing Kecamatan. Hal ini tampaknya berimplikasi terhadap pilihan-pilihan politik yang diambil oleh penduduk di Kota Medan dalam pilkada gubernur Sumatera Utara dimana isu agama, isu etnisitas dan isu-isu ke-daerahan 'putra daerah' menjadi vote getter untuk meraih tampuk kekuasaan.
\end{abstract}

Kata kunci: Demografi Politik, Vote Getter, Pemilihan Kepala Daerah

\section{PENDAHULUAN}

Mendefinisikan demografi politik merupakan bagian yang sangat sulit dalam tulisan ini. Terbatasnya literatur yang membahas tentang demografi politik secara kongkrit memberikan sinyalemen bahwa kajian demografi politik penting untuk dikaji lebih jauh dalam kajian ilmu politik. Untuk menerjemahkan defenisi demografi politik, tulisan ini diawali dengan pendefinisian makna demografi itu sendiri. Keyfitz mengatakan bahwa demografi merupakan analisis terhadap variable kependudukan yang di dalamnya tercakup aneka metode perhitungan dan hasil substantif mengenai angka kematian, kelahiran, migasi penduduk dan jumlah populasi penduduk (2000; 219). Keyfitz menambahkan bahwa demografi merupakan kajian interdisipliner yang bisa saja menggandeng ilmu-ilmu lainnya seperti ilmu politik, sosiologi, antropologi dan sebagainya.

Tulisan ini tidaklah memfokuskan kepada dua variabel yang ditekankan oleh pakar demografi yakni variable stok yang bersifat statis dan variable flow yang bersifat dinamis (2000; 219). Oleh sebab itu, kajian ilmu politik memasuki ranah demografi 
tatkala ada perubahan-perubahan perilaku, budaya, dari masing-masing penduduk sebagai akibat dari perubahan-perubahan sistem politik. Dengan bahasa yang lain Youke (dalam Lupiyanto, 2014) mengatakan bahwa variabel demografi akan sering berhubungan dengan variabel nondemografi, dan hubungan tersebut melahirkan demografi politik yang mempelajari hubungan aspek penduduk dan dinamika politik.

Hal inilah yang dikatakan oleh Tirtosudarmo dalam demografi tidak hanya sebatas melihat jumlah penduduk dengan angka kuantitatif semata, melainkan juga harus dilihat secara holisitik yang disebutnya melalui pendekatan Kebudayaan (2007; 6). Bagi Tirtosudarmo dalam pendekatan kebudayaan migrasi penduduk ataupun pola persebaran penduduk tidak semata-mata perpindahan belaka, namun pola persebaran penduduk juga dapat dipandang sebagai proses perpindahan sumber daya sosialbudaya $(2007 ; 6)$ maupun etnis dan agama.

Kajian demografi bukanlah kajian yang baru dalam khazanah keilmuan di Indonesia. Selama ini, kajian demografi cenderung terbatas pada penyuguhan data yang bersifat angka-angka yang meliputi komposisi penduduk, laju pertumbuhan dan kepadatan penduduk serta meliputi berbagai perubahan-perubahan tentang data kependudukan (fertilitas, mortalitas dan migrasi kependudukan). Meminjam istilah yang digunakan oleh Permana bahwa kajian demografi acap kali dikaitkan dengan dengan angka-angka statistik numerik yang domainnya lebih mengarah kepada studi kependudukan yang kemudian angka-angka tersebut terpatri dalam sebuah tabulasi sehingga dapat dijadikan sebagai rujukan bagi orang-orang yang bekepentingan dengan data-data tersebut (Permana, 2013). Tak ayal bila, sebagian orang berpendapat bahwa kajian demografis cenderung bersifat statis dan tidak begitu menarik. Namun tidak bisa dipungkiri juga kajian demografi memiliki kontiribusi untuk mendukung eksistensi khazanah keilmuan yang ada saat ini baik ilmu eksakta, ekonomi, geografi, antropologi, sosiologi, kesehatan maupun bagi ilmu politik.

Dekade 1980-an Orde Baru pernah melakukan kebijakan transmigrasi bagi orang-orang dari pulau Jawa ke pulau Sumatera, Kalimantan, Sulawesi maupun daerah lainnya di Indonesia. Sekilas tampak bahwa kebijakan tersebut untuk menahan laju pertumbuhan yang cepat di Pulau Jawa dan sekaligus untuk mengisi kekosongan di wilayah-wilayah yang sedikit penduduknya. Kajian demografi yang menyuguhkan berbagai macam data kependudukan dijadikan sebagai legitimasi para penguasa untuk menerapkan kebijakannya. Namun tidak bisa dipungkiri bahwa identitas etnis, agama dan identitas budaya yang melekat bagi setiap penduduk yang melakukan transmigrasi berdampak banyak hal bagi eksistensi kehidupan sosial, agama dan budaya penduduk lokal. Peleburan budaya baru dengan budaya lokal dapat menimbulkan dua sisi yakni sisi positif dan sisis negatif. Peleburan budaya akan berdampak positif jika masing-masing budaya yang mereka miliki mampu meredam setiap konflik yang ada, dan juga bisa mengarah kepada negatif jika masingmasing identitas mereka memiliki tingkat kecurigaan tinggi antara yang satu dengan yang lainnya. Hal inilah yang tampaknya luput dari kajian demografi yang sangat positivisitik dan tidak memperhatikan dampak-dampak lain dari perubahan komposisi penduduk.

Muncul pertanyaan bagi kita, seberapa pentingkah kajian demografi untuk melihat dinamuka politik saat ini? Mengapa Demografi Politik dianggap mampu untuk 
melihat tren sikap politik penduduk Indonesia?

Bagi kalangan ilmuan politik di Indonesia, kajian demografi berkontribusi melahirkan lembaga-lembaga konsultan politik yang melakukan kegiatan survey politik. Perubahan sistem pemilu di Indonesia yang semula bersifat otoritatif dan kini mengacu kepada pemilihan langsung yang dimulai tahun 2004 memberikan ruang tersendiri bahwa kajian-kajian demografi menjadi rujukan utama dalam penyajian data-data kependudukan yang bisa diterjemahkan untuk melihat serta menakar pilihan-pilihan politik yang akan diambil oleh setiap penduduk yang memiliki hak-hak politiknya. Oleh sebab itu, munculnya hibridasi antara kajian demografi dengan kajian politik yang melahirkan sebuah kajian demografi politik yang secara sederhana dapat dimaknai dengan penggalian datadata kependudukan serta perubahanperubahan sosial kependudukan yang disajikan dengan pembahasan-pembahasan politik.

Saat ini, kajian demografi politik Indonesia cepat berevolusi pasca reformasi tahun 1997-1998 terutama berkaitan tentang perubahan perilaku masyarakat sebagai akibat berubahnya dari sistem politik Indonesia. Jika pada pemilu tahun 1999 kajian demografi hanya dimanfaatkan sebagai pemberian data-data kependudukan semata, maka pada pemilu tahun 2004 (baik pemilihan anggota legislatif/pemilihan kepala daerah bupati dan walikota) hingga pemilu serentak yang akan digelar tahun 2019 kajian demografi politik memiliki berbagai macam fungsi penting; (1) kajian demografi politik menjadi rujukan bagi kalangan elit politik maupun partai politik sebagai bahan pertimbangan untuk berkontestasi dalam pertarungan politik karena demografi politik dapat menyuguhkan data yang dimulai dari data tingkat keterkenalan seseorang, tingkat kesukaan seseorang bahkan sampai pada tingkat keterpilihan seseorang yang dapat diprediksi dengan tingkat ke akuratan yang tinggi. (2) kajian demografi politik dapat melacak tingkat kepuasaan masyarakat terhadap kinerja pemerintahan yang ada. Bahkan kajian demografi politik dapat menjadi rujukan utama bagi para pemimpin untuk mengambil langkah-langkah kebijakan strategis. (3) istilah dunia politik 'adalah dunia yang abu-abu' kini tidak lagi menjadi pakem yang resmi, karena dengan kajian demografi politik dapat dijadikan alat untuk memprediksi tentang dinamika politik yang berkembang di even-even politik berikutnya.

Tulisan ini sebenarnya ingin melihat demografi politik di Sumatera Utara dari hasil pemilihan Gubernur Sumatera Utara yang telah selesai diselenggarakan pada tanggal 27 Juni 2018 yang dilihat dari pola persebaran penduduk, agama dan persebaran etnis. Namun tulisan ini juga membatasi ruang gerak kajiannya yang hanya membatasi pada wilayah Kota Medan dengan 21 Kecamatan sebagai fokus utama untuk melihat demografi politik pada pemilihan Gubernur Sumatera Utara. Kota Medan dianggap penting sebagai lokus utama untuk melihat demografi di Sumatera Utara karena Kota ini, merupakan salah satu Kota yang memiliki tingkat keragaman yang tinggi mulai dari komposisi persebaran penduduk, agama, dan maupun dari persebaran etnis. Selain itu, Kota Medan juga dapat dikategorikan sebagai barometer dinamika politik yang ada di Sumatera Utara. Langkah selanjutnya yang hendak dituju dalam tulisan ini adalah mencoba melihat kemungkinan seperti apa dinamika politik di Sumatera Utara menjelang Pemilu serentak (Pemilu Presiden dan Wakil Presiden, Pemilihan Legislatif, Pemilihan DPD) pada tanggal 27 April 2019. 


\section{Demografi Politik Kota Medan}

Dinamika politik kota Medan menyajikan sebuah fenomena yang unik. Selain tingkat keragaman agama, etnis yang tinggi, ternyata pola persebaran penduduk di Kota Medan juga memiliki karakteristik yang unik dalam penentuan pilihan-pilihan politiknya. Hal lain yang tidak bisa dipisahkan dalam dinamika politik di Kota Medan adalah masih kuatnya pendekatanpendekatan primordial yang kerap berselingkuh dengan tiga jalinan terlarang yakni hubungan antara pengusaha, penguasa, premanisme dalam kontestasi politik. Secara gamblang Hadiz (2005) mengatakan bahwa sangat sulit untuk menyaingi Sumatera Utara dalam sosial likaliku kekuatan politik dari pengaruh premanisme, dan kekuatan premanisme mempunyai sejarah yang panjang di Provinsi ini.

Ini Medan Bung, merupakan simbolisasi yang menunjukkan bagaimana kerasnya kehidupan sosial di Kota Medan. Gaya suara yang keras, sifat pemberani, adalah karakter yang khas dari slogan ini. Di Kota Medan kita sangat akrab dengan banyak organisasiorganisasi kepemudaan yang dimulai dari organisasi Pemuda Pancasila (PP), Ikatan Pemuda Karya (IPK), KNPI, AMPI, FKPPI dan sebagainya (Mukmin, 2010). Pada masa Orde Baru keberadaan organisasi kepemudaan bisa di katakan di bawah satu wadah partai politik yakni Golkar yang bertujuan untuk mendukung dan serta menjaga eksistensi suara Golkar pada pemilihan umum. Namun setelah reformasi bergulir keberadaan organisasi ini mempunyai fungsi yang berbeda. Organisasi-organisasi kepemudaan yang banyak berdiri kerap di jadikan sebagai basis untuk mencari nama dan pengaruh kekuasaan, serta di jadikan sebagai alat untuk melakukan praktek pungli di berbagai pusat kegiatan bisnis.

Selain organisasi kepemudaan, organisasi-organisasi keagamaan juga banyak eksis di Kota Medan, yang dimulai dari Organisasi Muhammadiyah, AlWashliyah, Nahdatul Ulama dari kalangan muslim, begitupun organisasi-organisasi dari agama Kristen, Organisasi Hindu dan Organisasi Konghucu dari kalangan etnis Tionghoa juga memainkan ritme dalam dinamika politik di Kota Medan. Dinamika politik Kota Medan semakin unik, tatkala pola persebaran penduduk menunjukkan identitas etnis, agama, budaya, dalam setiap kontestasi politik (Mukmin, 2010).

Kajian demografi politik menjadi kajian yang dapat dijadikan alat analisis untuk melihat perubahan-perubahan perilaku politik dari masyarakat yang ada di Kota Medan. Selain, untuk melihat perubahan perilaku politik, demografi politik juga dapat dijadikan alat analisis untuk memprediksi bagaimana perubahan perilaku politik untuk tahun-tahun kedepannya. Jika dilihat dari komposisi penduduknya, maka penduduk Kota Medan berjumlah 2.29.408 jiwa (BPS Kota Medan, 2016). 


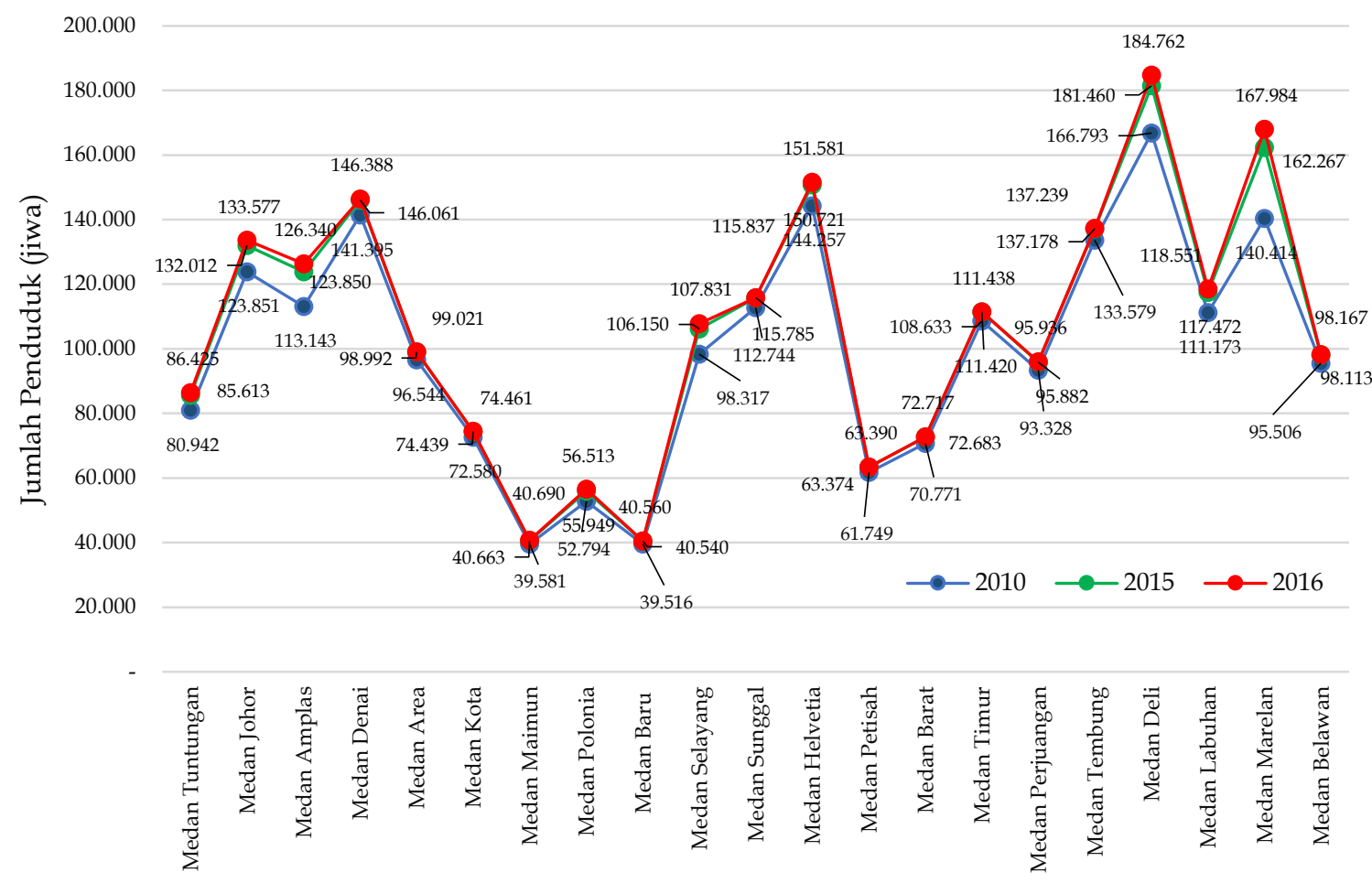

Gambar 1. Grafik Pertumbuhan penduduk Kota Medan pada rentang waktu Tahun 2010, 2015, dan 2016 (Sumber: Analisis Data BPS Kota Medan-Statistics of Medan Municipality, Population on December 2016)

Gambar 1 menunjukkan bahwa jumlah penduduk terbanyak di Kota Medan terletak di Kecamatan Medan Deli yaitu sebanyak 184.762 jiwa dengan laju pertumbuhan tahun 2015-2016 sebanyak 1,82\%. Posisi kedua terletak di kecamatan Medan Marelan dengan jumlah penduduk 167.984 jiwa dengan laju pertumbuhan kurun waktu 2015-2016 sebanyak 3,52\%, dan diurutan ketiga jumlah penduduk terbanyak terletak di kecamatan Medan Helvetia dengan jumlah 151.581 jiwa dengan laju pertembuhan kurun waktu 2015-2016 sebanyak 0,57\%. Dilain pihak kecamatan yang jumlah penduduknya paling sedikit terletak di kecamatan Medan Baru dengan jumlah penduduk 40.560 jiwa, kecamatan Medan Maimun dengan jumlah penduduk 40.690 jiwa dan Medan Polonia dengan jumlah penduduk 56.513 jiwa.

Pola persebaran penduduk di Kota Medan memang memiliki cacatan yang unik. Indikasi itu dapat dilihat dari pola persebaran domisili penduduk di Kota Medan membawa ciri khas dan identitas masing-masing baik dari segi agama, etnis bahkan sampai kepada afilisasi politiknya. Demografi dari domisili penduduk yang dilihat dari basis agama/perkecamatan dapat dilihat pada Tabel 1. 


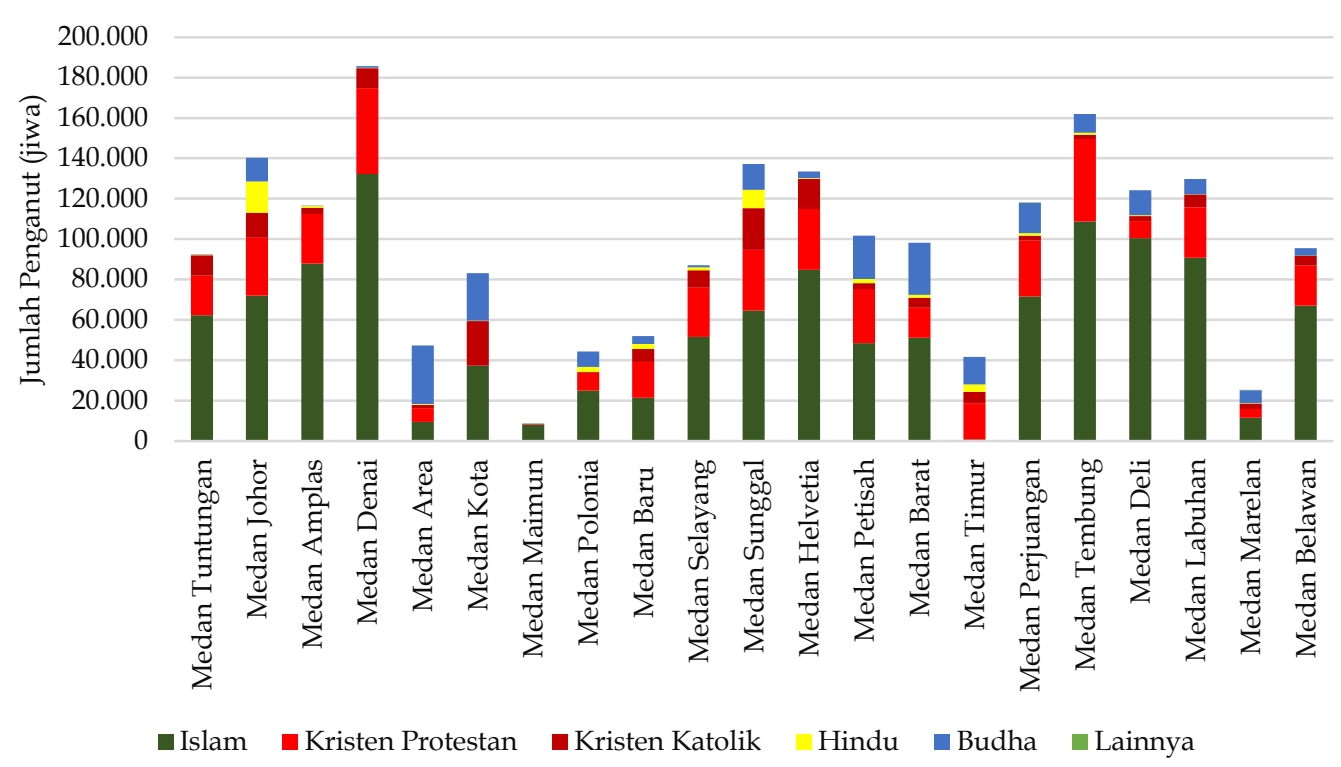

Gambar 2. Sebaran Penduduk Berdasarkan Agama di Kota Medan/Kecamatan

(Sumber: Kantor Kementrian Agama Kota Medan yang dikutip dari BPS Kota Medan, 2016)

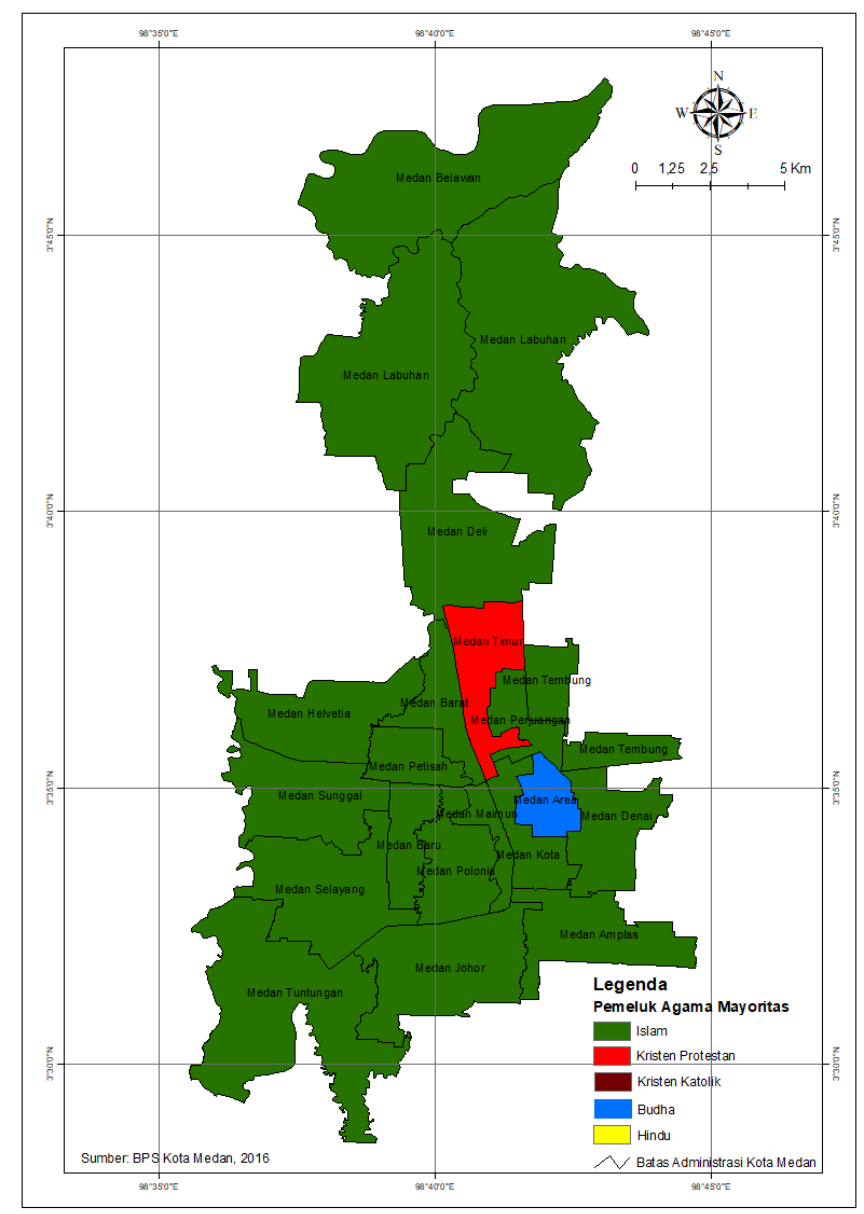

Gambar 3. Peta Sebaran Pemeluk Agama Mayoritas tiap Kecamatan di Kota Medan 
Secara keseluruhan, agama Islam merupakan agama mayoritas penduduk Kota Medan (Gambar 2). Terdapat 19 Kecamatan yang mayoritas penduduknya beragama Islam, satu kecamatan yang mayoritas penduduknya beragama Kristen Protestan yaitu di Kecamatan Medan Timur, dan satu kecamatan yang mayoritas penduduknya beragama Buddha yaitu di Kecamatan Area (Gambar 3). Hanya saja, data ini tidak dapat dijadikan bahwa terdapat dominasi penuh dari satu agama. Tabulasi di atas sebenarnya menunjukkan kondisi dimana pada masing-masing kecamatan tingkat pluralitas agama cukup tinggi. Dalam kajian ilmu politik, tentu saja tabulasi di atas memiliki makna penting karena acap kali pilihan-pilihan politik dari masing-masing penduduk didasarkan pada pilihan agama.

Tidak adanya dominasi dari etnis tertentu yang ada di Kota Medan juga memberikan sinyalemen bahwa Kota ini juga memiliki tingkat keragaman yang tinggi dari segi etnisitasnya. Beberapa pengamat mengatakan bahwa semakin tinggi tingkat keragaman etnis tidak menutup kemungkinan semakin tinggi ruang-ruang konflik terbuka. Pada Tabel 1 disajikan tabulasi data persebaran persebaran penduduk berdasarkan etnis yang terkonsentrasi pada beberapa kecamatan.

Tabel 1. Pola persebaran penduduk berdasarkan etnis/perkecamatan

\begin{tabular}{|c|c|c|c|}
\hline No & Jenis Suku & Persentase $\%$ & Basis Kecamatan \\
\hline 01 & Jawa & $12,85-59,42 \%$ & Medan Deli, Medan Marelan, Medan Polonia \\
\hline 02 & Melayu & $2,22-23,65 \%$ & Medan Labuhan, Medan Marelan, Medan Belawan \\
\hline 03 & Tapanuli/Toba & $5,31-26,78 \%$ & $\begin{array}{l}\text { Medan Kota, Medan Medan Denai, Medan } \\
\text { Helvetia, }\end{array}$ \\
\hline 04 & Tionghoa & $0,20-29,94 \%$ & $\begin{array}{l}\text { Medan Area, Medan Kota, Medan Maimun, Medan } \\
\text { Petisah, Medan Barat, Medan Maimun }\end{array}$ \\
\hline 05 & Tapsel/Madina & $4,48-24,36 \%$ & $\begin{array}{l}\text { Medan Tembung, Medan Barat, Medan Timur, } \\
\text { Medan Amplas }\end{array}$ \\
\hline 06 & Karo & $0,64-32,50 \%$ & Medan Baru, Medan Selayang, Medan Tuntungan \\
\hline 07 & Simalungun & $0,63-3,28 \%$ & Medan Selayang, Medan Tuntungan, \\
\hline 08 & Pakpak/Dairi & $0,20-2,48 \%$ & Medan Johor, Medan Tuntungan \\
\hline 09 & Nias & $0,18-1,82 \%$ & Medan Tuntungan, Medan Johor, Medan Amplas \\
\hline 10 & Pesisir/Tapteng & $0,09-0,61 \%$ & Medan Barat, Medan Belawan, Medan Johor \\
\hline 11 & Minangkabau & $2,77-30,93 \%$ & $\begin{array}{l}\text { Medan Area, Medan Denai, Medan Maimun, } \\
\text { Medan Kota }\end{array}$ \\
\hline 12 & Tamil/India & $0,09-6,27 \%$ & Medan Polonia, Medan Petisah, Medan Baru \\
\hline 13 & Arab & $0,02-0,35 \%$ & Medan Area, Medan Timur, Medan Perjuangan \\
\hline & Jumlah & $100,00 \%$ & \\
\hline
\end{tabular}

Sumber diolah dari data BPS Kota Medan: Persentase Penduduk Kota Medan Menurut Suku tahun 2004.

Data yang tersaji di atas merupakan data yang dioalah dari BPS Kota Medan pada tahun 2004. Pencarian data terkini yang berkaitan tentang peta persebaran penduduk berdasarkan etis memang terasa sulit karena tidak semua tersedia di dalam website BPS Kota Medan. Namun data ini masih cukup relevan untuk melihat letak dimana konsentrasi persebaran penduduk berdasarkan persebaran etnis.

Jika melihat tabulasi di atas, etnis Jawa merupakan etnis terbesar yang mencapai $31,43 \%$, kemudian di ikuti oleh etnis Batak yang terdiri dari beberapa cluster mencapai $17,51 \%$, etnis Tionghoa yang berada di Kota Medan mencapai 11,34\%, sedangkan 
keberadaan etnis Melayu mencapai 2,22\% hingga $23,28 \%$.

Karakter dari berbagai etnis yang memiliki keahlian tertentu ternyata mempengaruhi pola pemukiman penduduk. Daerah-daerah pusat perkotaan sebagai pusat perdagangan cenderung di dominasi dari dua etnis, yakni etnis Tionghoa dan etnis Minangkabau. Gedung-gedung pertokoan yang sekaligus di jadikan sebagai tempat tinggal adalah karakter khas dari pelaku ekonomi etnis Tionghoa. Di laih pihak etnis Minangkabau terkonsentrasi di pusat kota Medan yang berprofesi sebagai pedagang kelas menengah kebawah, sebagai penjual pakaian, membuka rumah makan khas Minang ataupun berprofesi sebagai pemotong rambut.

Daerah Medan Denai yang menjadi pusat perkantoran maupun pusat pemerintahan banyak di huni oleh etnis Batak Tapanuli. Aktifitas perdagangan sebenarnya juga di lakukan oleh etnis Batak ini, akan tetapi perdagangannya berbeda dengan apa yang di lakukan oleh etnis Minang ataupun etnis Tionghoa. Kegiatan perdagangan yang sering di lakukan oleh etnis Batak ini adalah berjualan buah-buahan ataupun berjualan sayur-mayur di pusat perbelanjaan.

Untuk etnis Jawa, sebahagian mereka memang ingin melepaskan predikat kuli dengan mencoba untuk mencari peruntungan ke pusat kota Medan dengan berprofesi sebagai pembantu rumah tangga, pramuniaga di pusat pertokoan Tionghoa ataupun sebagai pelayan di sebuah restauran. Sebahagian besar penyebaran dari etnis Jawa masih tetap berada di bekasbekas perkebunan dahulu yakni daerah Medan Deli.

Jika etnis Batak Toba/Tapanuli, Etnis Tionghoa, Minang, maupun Jawa berlombalomba untuk mencari peruntungan baru ke pusat-pusat perdagangan, maka hal ini tidak terjadi dengan etnis Melayu dan etnis
Mandailing. Etnis Melayu dan Mandailing tidak terlalu berminat untuk menetap di pusat-pusat kegiatan perekonomian. Mereka cenderung mencari daerah-daerah yang tingkat ketenangan cukup tinggi. Etnis Melayu dan Mandailing memilih menjual rumah-rumah mereka yang berada di pusat kota Medan dan kemudian mereka membeli rumah di pinggiran Kota Medan (Pelly, 2007; 686). Dari segi pekerjaannya biasanya mereka berprofesi sebagai guru di madrasah-madrasah sampai menjadi pengajar di perguruan tinggi.

\section{PEMBAHASAN}

Pemilihan Gubernur Sumatera Utara yang diselenggarakan tanggal 27 Juni tahun 2018 telah selesai dilaksanakan dan telah menahbiskan pasangan Edy Rahmayadi dan Musa Rajekshah sebagai pemenang dengan mengatongi $57,41 \%$ atau total memperoleh 3.234.017 suara dan mengalahkan pasangan Djarot Saiful Hidayat yang berpasangan dengan Sihar P.H Sitorus yang memperoleh $42,59 \%$ atau memperoleh 2.399.218 suara (KPU, 2018). Untuk Kota Medan sendiri, jumlah total pemilih dalam pemilihan Gubernur Sumatera Utara berjumlah 1.548. 887 dan pemilih yang menggunakan hak pilih dalam pemilihan Gubernur tahun 2018 berjumlah 925.334 (KPU, 2018). Tingkat partisipasi pemilih dalam Pemilihan Gubernur Sumatera Utara pada tahun 2018 mengalami peningkatan jika dibandingkan dengan pemilihan Gubernur pada pada tahun 2013 silam. Pada pemilihan Gubernur Sumatera Utara pada tahun 2013 di Kota Medan jumlah partisipasi pemilih hanya mencapai $36,62 \%$ dan pemilih yang tidak berpartisipasi berkisar 63,38\% (Detik.com, 12/03/2013). Pada pemilihan Gubernur Sumatera Utara tahun 2018 Total partisipasi pemilih dalam pemilihan Gubernur Sumuatera Utara berjumlah 58,39\% dimana tingkat partisipasi pemilih laki-laki 
berjumlah 55,96\% dan tingkat partisipasi pemilih perempuan berjumlah 60,72\% (KPU, 2018).
Berikut ini adalah rekapitulasi hasil suara dari pemilihan Gubernur Sumatera Utara tahun 2018 yang dilihat dari 21 Kecamatan yang ada di Kota Medan.

Tabel 2. Rekapitulasi Hasil Perolehan Suara Pasangan Calon/Kecamatan di Kota Medan

\begin{tabular}{|c|c|c|c|c|c|c|c|}
\hline \multirow[t]{2}{*}{ No } & \multirow[t]{2}{*}{ Kecamatan } & \multirow[t]{2}{*}{$\begin{array}{l}\text { Jumlah } \\
\text { Pemilih }\end{array}$} & \multirow[t]{2}{*}{$\begin{array}{l}\text { Pengguna } \\
\text { Hak Pilih }\end{array}$} & \multirow{2}{*}{$\begin{array}{c}\text { Tingkat } \\
\text { Partisipasi } \\
\text { Pemilih }\end{array}$} & \multirow[t]{2}{*}{ Total Suara } & \multicolumn{2}{|c|}{$\begin{array}{c}\text { Pasangan } \\
\text { Gubernur/Wakil } \\
\text { Gubernur }\end{array}$} \\
\hline & & & & & & ERAMAS & DJOSS \\
\hline 01 & Medan Tuntungan & 65244 & 39.372 & $60,3 \%$ & 38.669 & $32,3 \%$ & $67,7 \%$ \\
\hline 02 & Medan Johor & 106.468 & 60.210 & $56,6 \%$ & 58.955 & $64,4 \%$ & $35,6 \%$ \\
\hline 03 & Medan Amplas & 81.033 & 49.783 & $61,4 \%$ & 48.846 & $69,4 \%$ & $30,6 \%$ \\
\hline 04 & Medan Denai & 105.524 & 61.035 & $57,8 \%$ & 60.519 & $64,0 \%$ & $36,0 \%$ \\
\hline 05 & Medan Area & 79.924 & 48.922 & $61,2 \%$ & 48.465 & $68,2 \%$ & $31,8 \%$ \\
\hline 06 & Medan Kota & 69.202 & 39.026 & $56,4 \%$ & 37.653 & $43,6 \%$ & $56,4 \%$ \\
\hline 07 & Medan Maimun & 41.614 & 21.170 & $50,9 \%$ & 21.291 & $68,2 \%$ & $31,8 \%$ \\
\hline 08 & Medan Polonia & 37.181 & 21.359 & $57,4 \%$ & 21.256 & $54,9 \%$ & $45,1 \%$ \\
\hline 09 & Medan Baru & 31.533 & 16.875 & $53,5 \%$ & 16.680 & $38,5 \%$ & $61,5 \%$ \\
\hline 10 & Medan Selayang & 70.956 & 42.760 & $60,3 \%$ & 42.340 & $51,2 \%$ & $48,8 \%$ \\
\hline 11 & Medan Sunggal & 88.124 & 47.917 & $54,4 \%$ & 46.668 & $63,5 \%$ & $36,5 \%$ \\
\hline 12 & Medan Helvetia & 99.374 & 61.425 & $61,8 \%$ & 61.091 & $56,7 \%$ & $43,3 \%$ \\
\hline 13 & Medan Petisah & 52.484 & 29.527 & $56,3 \%$ & 29.541 & $40,2 \%$ & $59,8 \%$ \\
\hline 14 & Medan Barat & 64.462 & 35.581 & $55,2 \%$ & 35.064 & $56,3 \%$ & $43,7 \%$ \\
\hline 15 & Medan Timur & 82.577 & 51.264 & $62,1 \%$ & 51.011 & $56,5 \%$ & $43,5 \%$ \\
\hline 16 & Medan Perjuangan & 73.758 & 44.822 & $60,8 \%$ & 44.135 & $57,6 \%$ & $42,4 \%$ \\
\hline 17 & Medan Tembung & 96.548 & 55.819 & $57,8 \%$ & 56.018 & $66,3 \%$ & $33,7 \%$ \\
\hline 18 & Medan Deli & 111.783 & 61.828 & $55,3 \%$ & 61.815 & $69,2 \%$ & $30,8 \%$ \\
\hline 19 & Medan Labuhan & 78.252 & 46.498 & $59,4 \%$ & 45.379 & $67,2 \%$ & $32,8 \%$ \\
\hline 20 & Medan Marelan & 84.986 & 55.218 & $65,0 \%$ & 54.823 & $80,6 \%$ & $19,4 \%$ \\
\hline 21 & Medan Belawan & 63.860 & 34.933 & $54,7 \%$ & 34.753 & $66,9 \%$ & $33,1 \%$ \\
\hline
\end{tabular}

Sumber; KPU RI yang di doanload dari

https://infopemilu.kpu.go.id/pilkada2018/hasil/cepat/t1/sumatera_utara/kota_medan

Keterangan;

- $\quad$ ERAMAS singkatan dari Pasangan Edy Rahmayadi dan Mus Rajeksha

- Djoss singkatan dari pasangan Djarot dan Sihar Sitorus

- Rekapitulasi ini tidak memasukkan data surat suara yang tida sah

Merujuk data rekapitulasi hasil perolehan suara dalam pemilihan Gubernur Sumatera Utara tahun 2018 yang disajikan oleh KPU, pasangan Edy Rahmayadi dan Musa Rajekshah (ERAMAS) unggul di 17 Kecamatan sedangkan pasangan Djarot dan Sihar Sitorus (Djoss) hanya unggul di 4 Kecamatan yakni Kecamatan Medan Tuntungan, Kecamatan Medan Kota, Kecamatan Medan Baru dan Kecamatan Petisah.

Tingginya tingkat pluralitas Kota Medan baik dari segi Agama, Etnis dan
Budaya memberikan efek yang besar terhadap isu yang berkembang dalam pemilihan Gubernur. Hampir sama dengan pemilihan Gubernur yang dilaksanakan pada tahun 2008, tahun 2013 sampai pemilihan Gubernur pada tahun 2018 bahwa isu yang berkembang pada pemilihan Gubernur Sumatera masih meliputi tiga aspek yang sama yakni; isu agama, politik identitas etnis, dan isu putra daerah (Sarumpaet dan Nababan, 2014). Oleh sebab itu, adu gagasan yang berkaitan visi dan misi dari masing-masing kandidat yang 
bertarung dalam pilkada tidak terlihat dengan jelas. Gagasan visi dan misi untuk membangun Sumatera Utara seolah-olah hanya terpampang dalam baliho, spanduk maupun dalam iklan kampanye di media cetak maupun online.

Dalam kajian politik dan demokrasi, tidak ada larangan untuk menggunakan isu agama, identitas etnis maupun isu putra daerah karena hal tersebut merupakan bagian dari cost politics. Hanya saja, jika kita melihat dari pembangunan dan konsolidasi demokrasi di Sumatera Utara, tentu saja hal ini sangat menghawatirkan karena hal yang terjadi justru pengkhianatan terhadap demokasi itu sendiri dengan munculnya politisasi agama, politisasi etnis dan politisasi isu putra daerah demi meraih tampuk kekuasaan. Oleh sebab itu, tulisan ini ingin melihat lebih jauh bagaimana tiga isu tersebut masih begitu kuat pada pemilihan Gubernur Sumatera Utara tak terkecuali pada Pilkada yang diselenggarakan tahun 2018.

\section{Isu Agama}

Pemilihan Gubernur Jakarta yang dilaksanakan pada tahun 2017 memberikan dampak yang luar biasa bagi dinamika politik di Indonesia pada umumnya tak terkecuali sangat berpengaruh pada pilkada di Sumatera Utara. Terlibatnya Djarot Saiful Hidayat dalam pilkada Gunernur Sumatera Utara yang nota bene adalah pasangan Ahok (Basuki T Purnama) ketika pilkada DKI berimplikasi pada tingginya sentimen agama dalam Pilkada Sumatera Utara. Meskipun Djarot merupakan seorang muslim ternyata hal tersebut tidak menghilangkan memori orang-orang di
Sumatera Utara bahwa beliau pernah berpasangan dengan Ahok yang dianggap menghina ummat Islam dengan cuitannya terhadap 'surat Almaidah'. Berpasangan dengan Sihar Sitorus yang beragama nasrani semakin mengukuhkan bahwa pilkada Sumatera Utara seolah-olah menjadi pertarungan agama. Hal inilah yang dikatakan oleh Rasmussen bahwa persoalan agama akan selalu penting bagi manusia dan agama memiliki kapasitas untuk mempengaruhi cara menjalani hidup dan cara bertindak seseorang dalam pengambilan keputusan, termasuk dalam pengambilan keputusan-keputusan politik (2013; 1359).

Merujuk rekapitulasi perolehan suara yang disajikan oleh KPU, dan dilihat dari persebaran penduduk berbasiskan agama tampaknya hal ini berbanding lurus dengan hasil perolehan suara yang diperoleh pada masing-masing kandidat. Kecamatankecamatan yang populasi penduduknya mayoritas beragama Islam menjatuhkan pilihan politik terhadap pasangan Edy Rahmyadi dan Musa Rajekshah. Dilain pihak 3 Kecamatan yang populasinya penduduknya Muslim lebih sedikit, pilihan jatuh kepada pasangan Djarot Saiful dan Sihar Sitorus. Berikut ini adalah konfigurasi pilihan-pilihan politik berdasarkan pola persebaran penduduk berdasarkan agama.

Sentimen agama memang menjadi penentu dalam pilkada Sumatera Utara pada tahun 2018. Merujuk tabulasi di atas dapat dilihat bahwa basis-basis penduduk yang ber-agama Islam menjatuhkan pilihan politik kepada pasangan Edy Rahmayadi dan Pasangan Musa Rajekshah (Gambar 4). 


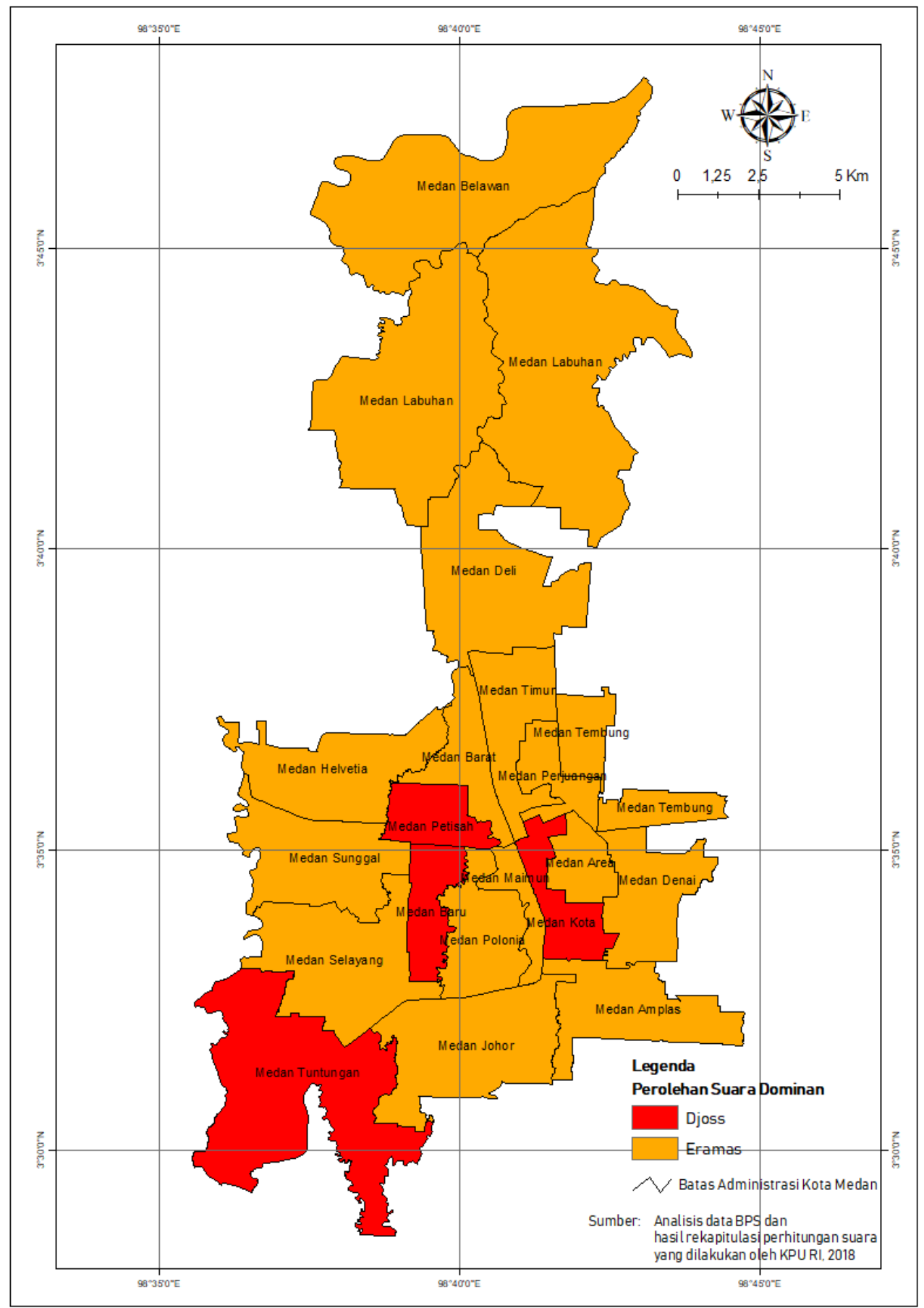

Gambar 4. Peta Sebaran Suara pada Pemilihan Gubernur 2018 di Kota Medan

Dilain pihak, basis-basis penduduk yang diluar basis agama Islam seperti Medan Kota, Medan Baru dan Medan Petisah yang lebih banyak konfigurasi agama Kristen (Katolik dan Protestan),
Budha, Hindu dan Konghucu tampaknya menjatuhkan pilihan kepada pasangan Djarot Saiful Hidayat dan Sihar Sitorus. Pilihan politik tersebut sebenarnya dapat dipahami karena sosok seorang Sihar Sitorus 
berasal dari agama kristen yang mereka anggap sama dengan identitas agama mereka. Beberapa kalangan etnis Tionghoa juga menjatuhkan pilihan politik kepada pasangan Djarot Saiful Hidayat dengan Sihar Sitorus, karena sebagian orang Tionghoa juga menganut ajaran agama Kristian.

Konsekuensi logis dari tidak adanya mayoritas agama di Kota Medan menjadikan kedua pasangan calon saling memperebutkan basis-basis agama sebagai vote getter diakar rumput. Oleh sebab itu, peningkatan partisipasi dalam pilkada Sumatera Utara pada tahun 2018 bisa jadi bukan karena didorong dengan semangat partisipasi politik yang baik sebagai upaya konsolidasi demokrasi, melainkan karena didorong oleh tingginya spirit kesamaan identitas-identitas agama. Secara teoritis prilaku politik yang terlihat dalam pilkada Sumatera Utara lebih kepada perilaku politik yang mengedepankan aspek pendekatan sosiologis dimana kesamaankesamaan baik berupa identitas gender, organisasi bahkan kesamaan agama berperan besar untuk menentukan pilihanpilihan politik masing-masing individu.

\section{Identitas Etnis}

Selain penggiringan agama sebagai vote getter diakar rumput, politik identitas etnis juga terjadi dalam pilkada Gubernur Sumatera Utara pada tahun 2018. Pertanyaan yang selalu muncul adalah, etnis mana yang berhak untuk memimpin Sumatera Utara? Dalam catatan beberapa penelitian yang telah dilakukan, muncul sebuah anekdot yang dikenal dengan 'Rehap Lunas' sebagai singkatan dari Siregar,
Harahap, Lubis dan Nasution yang selalu menjadi pemegang kekuasaan (Nuryanti, 2004; 208). Perlahan-lahan dominasi etnis batak mulai terkikis dengan naiknya beberapa calon gubernur dan wakil gubernur yang berlatar belakang dari etnis Jawa, Melayu, maupun dari Tionghoa. Menjadi catatan bagi penting bahwa isu ini juga mempunyai tingkat sensitifitas yang hampir sama dengan isu agama yang bisa saja memunculkan sebuah konflik bersifat komunal seperti apa yang terjadi pada pemilihan kepala daerah dibeberapa daerah lainnya.

Dari kedua kandidat yang saling bertarung dalam pilkada Gubernur Sumatera Utara tahun 2018 memainkan identitas etnis untuk sebagai pendulang suara diakar rumput. Tentu saja, hal ini sangat menghawatirkan bagi perkembangan demokrasi karena fungsi dari partai politik tidak berjalan dengan baik sebagai akomodasi dari kepetingan masyarakat Sumatera Utara. Ada kesan bahwa para kandidat yang berkompetisi dalam pemilihan gubernur mengejar perkumpulan-perkumpulan ataupun paguyuban-paguyuban yang yang diwadahi oleh berbagai etnis (etnis batak, etnis jawa, etnis melayu, minangkabau, tamil dan tionghoa) dan agama untuk menjadi mesin pendulang suara yang efektif. Hal ini dapat terjadi mengingat tidak ada etnis ataupun agama yang dominan. Sangat wajar jika politik identitas etnis dan agama akan dijadikan sebagai mesin kekuatan politik yang mempengaruhi para pemilih. Berikut ini adalah tabulasi rekapitulasi perolehan suara berbasis sentimen etis di Kota Medan. 
Tabel 3. Rekapitulasi hasil perhitungan suara berdasarkan domisili berbasiskan Etnis

\begin{tabular}{|c|c|c|c|c|c|}
\hline N0 & Jenis Suku & $\begin{array}{c}\text { Persentase } \\
\%\end{array}$ & Basis Kecamatan & $\begin{array}{c}\text { Edy Rahmayadi } \\
\text { dan Musa } \\
\text { Rajekshah }\end{array}$ & $\begin{array}{c}\text { Djarot Saiful } \\
\text { Hidayat dan Sihar } \\
\text { Sitorus }\end{array}$ \\
\hline \multirow[t]{3}{*}{01} & \multirow[t]{3}{*}{ Jawa } & \multirow{3}{*}{$\begin{array}{c}12,85-59,42 \\
\%\end{array}$} & Medan Deli & $69,2 \%$ & $30,8 \%$ \\
\hline & & & Medan Marelan & $80,6 \%$ & $19,4 \%$ \\
\hline & & & Medan Polonia & $54,9 \%$ & $45,1 \%$ \\
\hline \multirow[t]{3}{*}{02} & \multirow[t]{3}{*}{ Melayu } & \multirow[t]{3}{*}{$2,22-23,65 \%$} & Medan Labuhan & $67,2 \%$ & $32,8 \%$ \\
\hline & & & Medan Marelan & $80,6 \%$ & $19,4 \%$ \\
\hline & & & Medan Belawan & $66,9 \%$ & $33,1 \%$ \\
\hline \multirow[t]{3}{*}{03} & \multirow[t]{3}{*}{ Tapanuli/Toba } & \multirow[t]{3}{*}{$5,31-26,78 \%$} & Medan Kota & $43,6 \%$ & $56,4 \%$ \\
\hline & & & Medan Denai & $64,0 \%$ & $36,0 \%$ \\
\hline & & & Medan Helvetia & $56,7 \%$ & $43,3 \%$ \\
\hline \multirow[t]{5}{*}{04} & \multirow[t]{5}{*}{ Tionghoa } & \multirow[t]{5}{*}{$0,20-29,94 \%$} & Medan Area & $68,2 \%$ & $31,8 \%$ \\
\hline & & & Medan Kota & $43,6 \%$ & $56,4 \%$ \\
\hline & & & Medan Maimun & $68,2 \%$ & $31,8 \%$ \\
\hline & & & Medan Petisah & $40,2 \%$ & $59,8 \%$ \\
\hline & & & Medan Barat & $56,3 \%$ & $43,7 \%$ \\
\hline \multirow[t]{4}{*}{05} & \multirow[t]{4}{*}{ Batak Tapsel } & \multirow[t]{4}{*}{$4,48-24,36 \%$} & Medan Tembung & $66,3 \%$ & $33,7 \%$ \\
\hline & & & Medan Barat & $56,3 \%$ & $43,7 \%$ \\
\hline & & & Medan Timur & $56,5 \%$ & $43,5 \%$ \\
\hline & & & Medan Amplas & $69,4 \%$ & $30,6 \%$ \\
\hline \multirow[t]{3}{*}{06} & \multirow[t]{3}{*}{ Karo } & \multirow[t]{3}{*}{$0,64-32,50 \%$} & Medan Baru & $38,5 \%$ & $61,5 \%$ \\
\hline & & & Medan Selayang & $51,2 \%$ & $48,8 \%$ \\
\hline & & & Medan Tuntungan & $32,3 \%$ & $67,7 \%$ \\
\hline \multirow[t]{2}{*}{07} & \multirow[t]{2}{*}{ Simalungun } & \multirow[t]{2}{*}{$0,63-3,28 \%$} & Medan Selayang & $51,2 \%$ & $48,8 \%$ \\
\hline & & & Medan Tuntungan & $32,3 \%$ & $67,7 \%$ \\
\hline \multirow[t]{2}{*}{08} & \multirow[t]{2}{*}{ Pakpak/Dairi } & \multirow[t]{2}{*}{$0,20-2,48 \%$} & Medan Johor, & $64,4 \%$ & $35,6 \%$ \\
\hline & & & Medan Tuntungan & $32,3 \%$ & $67,7 \%$ \\
\hline \multirow[t]{3}{*}{09} & Nias & $0,18-1,82 \%$ & Medan Tuntungan & $32,3 \%$ & $67,7 \%$ \\
\hline & & & Medan Johor & $64,4 \%$ & $35,6 \%$ \\
\hline & & & Medan Amplas & $69,4 \%$ & $30,6 \%$ \\
\hline 10 & Pesisir/Tapteng & $0,09-0,61 \%$ & Medan Barat & $56,3 \%$ & $43,7 \%$ \\
\hline & & & Medan Belawan & $66,9 \%$ & $33,1 \%$ \\
\hline & & & Medan Johor & $64,4 \%$ & $35,6 \%$ \\
\hline 11 & Minangkabau & $2,77-30,93 \%$ & Medan Area & $68,2 \%$ & $31,8 \%$ \\
\hline & & & Medan Denai & $64,0 \%$ & $36,0 \%$ \\
\hline & & & Medan Maimun & $68,2 \%$ & $31,8 \%$ \\
\hline & & & Medan Kota & $43,6 \%$ & $56,4 \%$ \\
\hline 12 & Tamil/India & $0,09-6,27 \%$ & Medan Polonia & $54,9 \%$ & $45,1 \%$ \\
\hline & & & Medan Petisah & $40,2 \%$ & $59,8 \%$ \\
\hline & & & Medan Baru & $38,5 \%$ & $61,5 \%$ \\
\hline 13 & Arab & $0,02-0,35 \%$ & Medan Area & $68,2 \%$ & $31,8 \%$ \\
\hline & & & Medan Timur & $56,5 \%$ & $43,5 \%$ \\
\hline & & & Medan Perjuangan & $57,6 \%$ & $42,4 \%$ \\
\hline
\end{tabular}

Sumber: diolah dari data BPS Kota Medan tahun 2004 dan diolah rekapitulasi perhitungan suara KPU RI tahun 2018

Jika kita membandingkan data yang tersaji pada Tabel 1 tentang domisili etnis berbasiskan kecamatan dengan rekapitulasi hasil suara yang disajikan oleh KPU, identitas etnis yang melekat pada masingmasing kandidat mempengaruhi para 
pemilih. Tabel di atas memberikan petunjuk bahwa karakter yang dimiliki para masingmasing kandidat mampu dimanfaatkan dengan baik. Kedekatan jarak emosional baik diwakili oleh sentimen marga (khusus bagi Batak), Melayu, Jawa, tampak melakukan afiliasi yang harmonis diantara beberapa kandidat. Untuk orang-orang etnis batak yang terdiri dari Batak Tapanuli Utara, Batak Toba, Batak Karo, Batak Simalungun, Batak Dairi dan Nias pilihan-pilihan politik jatuh pada pasangan Djarot dan Sihar Sitorus. Sosok seorang Sihar yang bermarga sitorus dan beragama kristen dianggap mewakili identitas etnis batak lainnya. Namun, anomali terjadi bagi figur seorang Djarot yang memiliki identitas etnis Jawa. Suara dari etnis jawa tidak seutuhnya penuh kepada Djarot, bahkan etnis jawa lebih banyak menjatuhkan pilihannya kepada pasangan Edy Rahmayadi dan Musa Rajekshah. Salah satu alasan mengapa etnis jawa suaranya terbelah di Kota Medan adalah karena figur Djarot tidak mewakili penuh suara-suara kebutuhan etnis jawa yang ada di Kota Medan.

Dilain pihak, pasangan Edy Rahmayadi dan Musa Rajekhshah didukung penuh oleh etnis Melayu sebagai akar basis massanya dari Edy Rahmayadi. Etnis Jawa, Mandailing, Minangkabau, Tamil, Aceh, dan Arab menjatuhkan pilihan kepada pasangan tersebut. Tertariknya etnis arab kepada pasangan ini tak lain dari hadirnya figur Musa Rajehkshah yang memiliki garis keturunan arab.

Bangkitnya politik identitas etnis dalam pilkada Sumatera Utara pada tahun 2018 menunjukkan bahwa dinamika politik lokal masih sangat sulit untuk dilepaskan dari bayang-bayang ikatan primordial. Hal inilah yang dikatakan oleh Cohen bahwa etnis merupakan sebuah fenomena politik, karena dalam etnis terkandung nilai-nilai tradisional yang memiliki karakter tertentu, dan dari karakteristik yang di miliki etnis dapat di gunakan sebagai mekanisme dari pensejajaran politik ketika terjadi interaksi di antara beberapa identitas etnis (Cohen 1996; 83-84).

\section{Isu Putra Daerah}

Isu putra daerah merupakan isu yang tak kalah penting dalam pilkada Sumatera Utara tahun 2018. Lihat saja isu yang digaungkan oleh pasangan Edy Rahmayadi dan Musa Rajekshah ketika debat publik yang dilaksanakan oleh KPUD Provinsi Sumatera Utara. Pasangan ini memberikan klaim bahwa putra daerah lah yang tau akar permasalahan yang ada di Sumatera Utara dan bukan pemimpin impor dari Jakarta yang mampu menyelesaikan permasalahan yang ada di Sumatera Utara. Slogan ini tentu saja tamparan untuk pasangan Djarot dan Sihar Sitorus dimana kita ketahui bersama bahwa Djarot bukan berasal dari Sumatera Utara.

Pendekatan ekologis sangat berpengaruh pada isu ini dimana asal-usul tempat kelahiran, tempat berkarir mempengaruhi pilihan-pilihan masyarakat yang ada di Kota Medan. Perubahan mekanisme dalam sistem pemilihan kepala daerah yang dilakukan secara langsung dan tidak lagi melalui meknisme DPRD pada tahun 2005 memberikan sumbangan besar atas meningkatnya isu putra daerah. Dari proses pemilihan secara otomatis akan berdampak langsung terhadap penciptaan kompetisi terbuka dalam mewujudkan konsolidasi demokrasi di tingkat lokal. Maka dari itu tidak bisa dipungkiri bahwa pencitraan politik untuk menaikkan elektabilitas dalam pemilihan kepala daerah sering menggunakan isu 'putra daerah' sebagai bahan kampanye untuk menggerakkan basis pemilih.

\section{KESIMPULAN}

Jatuhnya rezim Orde Baru, pergulatan politik identitas agama, identitas etnis dan sentiment kedaerahan karakter 
yang khas dalam dinamika politik lokal yang ada di Indonesia tak terkecuali di Sumatera Utara. Untuk Kota Medan sudah menjadi rahasia umum apabila dalam setiap kontestasi politik, identitas etnis, agama dan isu putra daerah kerap dijadikan instrumen vote getter. Jika dilihat dari hubungan interaksi sosial antara etnis yang ada di Medan, pada dasarnya hubungan itu berjalan dengan normal. Akan tetapi tidak bisa dipungkiri juga bahwa tingkat kecurigaan diantara masing-masing etnis itu sangat tinggi. Efek yang ditimbulkan dari kecurigaan itu dimana antara etnis tersebut saling mengandalkan ikatan primordial yang ada sebagai basis pergerakan politik jika berhadapan dengan kontestasi politik. Dominasi etnis Batak, Melayu, Jawa, Tionghoa dalam memperoleh jabatanjabatan politik merupakan indikasi kuat bagaimana kedua etnis tersebut mampu mengelola potensi kekuatan etnis sebagai basis pendukung untuk menduduki pos-pos kekuasaan.

Demografi Politik di Sumatera Utara pasca pilkada Gubernur Sumatera Utara pada tahun 2018 setidaknya memberikan gambaran bagaimana potensi untuk melihat kontestasi politik tahun kedepannya. Perhelatan politik akbar seperti pemilu serentak baik pemilu Presiden, DPR RI, DPD, DPRD Provinsi dan DPRD Kabupaten/Kota tahun 2019 untuk wilayah Sumatera Utara harus benar-benar mempertimbangkan banyak hal yang harus diketahui seperti bagaimana menetapkan isu-isu yang tepat jika dilihat pada tingkat usia penduduk di Kota Medan, menetapkan paket kebijakan apa yang cocok dikampanyekan jika dilihat dari tingkat pendidikan dan pertumbuhan ekonomi penduduk di Kota Medan dan menetapkan tema kampanye seperti apa yang tepat untuk menarik para pemilih jika dilihat dari segi gender. Namun beberapa hal di atas bisa saja tidak berjalan sesuai dengan apa yang direncanakan ketika para masing- masing para kandidikat yang berkontestasi abai terhadap tiga isu utama yakni isu bagaiamana mengemas isu agama yang relevan, bagaimana pengelolaan isu-isu identitas etnis, dan isu kedaerahan yang berkaitan tentang akomodasi kepentingankepentingan daerah.

\section{DAFTAR PUSTAKA}

BPS Kota Medan. (2017). Medan dalam Angka 2017.

Cohen, A. (1996). Ethnicity and politics. Ethnicity, 83-84.

Detik.com. (2013). Angka Golput di Medan dalam Pilgub SUMUT Mencapai 63, 38\%. 12 Maret 2013

Hadiz, V. R. (2005). Dinamika kekuasaan: ekonomi politik Indonesia pascaSoeharto. LP3ES.

KPU Republik Indonesia. (2018). Rekapitulasi Pemilihan Gubernur Sumatera Utara. Didownload dari https://infopemilu.kpu.go.id/pilka da2018/hasil/cepat/t1/sumatera_ut ara/kota_medan

Keyfitz, N. (2000). Demography. Dalam Ensiklopedia Ilmu-Ilmu Sosial. PT Raja Grafindo Persada. Jakarta.

Lupiyanto, Ribut. (2014). “Demografi Politik Pemilu 2014" dalam Kompas. Edisi $30 / 1 / 2014$

Mukmin, B. A. (2010). Politik Etnis Tionghoa di Kota Medan. Tesis. Program Studi Ilmu Politik Pasca Sarjana. Universitas Gadjah Mada. Yogyakarta.

Sarumpaet, B. A. M., \& Nababan, R. (2014). Afiliasi Politik Etnis Tionghoa di Kota Medan Dalam Pemilihan Gubernur Sumatera Utara 
2013. Jurnal Kewarganegaraan, 22(01), 85-103.

Nuryanti, S. (2007). Kinerja DPRD Medan dan Simalungun. Partai dan Parlemen Lokal Era Transisi Demokrasi di Indonesia. LIPI, Jakarta.

Pelly, U. (2007). Orang Melayu di Kota Medan. dalam Koentjaraningrat, Masyarakat Melayu dan Budaya Melayu dalam Perubahan. Balai Kajian dan Pengembangan Budaya Melayu dan Adicita. Karya Nusa, Yogyakarta.

Rasmussen, Bryan, A.S. (2013). Agama dan Politik Amerika. dalam Ilmu Politik Dalam Paradigma. Abad Ke-21 Jilid II. Kencana Prenada Media Grup. Jakarta.

Tirtosudarmo, R. (2007). Mencari Indonesia Demografi Politik Pasca-Seoharto. LIPI. Jakarta.

Permana, Y. S. (2013). Sekilas tentang Politik Demografi. didownload melalui http://www.politik.lipi.go.id/kolo $\mathrm{m} /$ kolom-2/politik-nasional/798sekilas-tentang-politik-demografi. 